\title{
OECONOMIA
}

COPERNICANA

\section{NR 4}

ISSN 2083-1277, (Online) ISSN 2353-1827

http://www.oeconomia.copernicana.umk.pl/

Jarecki W. (2013), Wzrost czy spadek wolności gospodarczej? Skutki współczesnego kryzysu gospodarczego, „Oeconomia Copernicana”, $\mathrm{nr}$ 4, ss. 5-17, DOI: http://dx.doi.org/10.12775/OeC.2013.028

Wojciech Jarecki ${ }^{*}$

Uniwersytet Szczeciński

\section{Wzrost czy spadek wolności gospodarczej? Skutki współczesnego kryzysu gospodarczego}

Klasyfikacja JEL: $E 12, E 13, E 32, E 44$

Słowa kluczowe: kryzys gospodarczy, wolność gospodarcza

Abstrakt: Celem opracowania jest poszukiwanie odpowiedzi na pytanie, czy kryzys gospodarczy lat 2007-2009 spowoduje spadek czy wzrost wolności gospodarczej. Poszukując odpowiedzi na to pytanie przeprowadzono analizę Indeksów Wolności Gospodarczej Instytutu Frasera w latach 2007-2010. Badaniami objęto Unie Europejska i Stany Zjednoczone.

(C) Copyright Instytut Badań Gospodarczych \& Polskie Towarzystwo Ekonomiczne Oddział w Toruniu

Tekst wpłynął 22 stycznia 2013 r., został zaakceptowany do publikacji 26 września $2013 \mathrm{r}$.

*Dane kontaktowe autora: wojciech.jarecki@wneiz.pl, Katedra Organizacji i Zarządzania, Zakład Zarządzania Kapitałem Ludzkim, WNEIZ, Uniwersytet Szczeciński, al. Papieża Jana Pawła II 22a, 70-453 Szczecin 


\title{
Greater or Reduced Economic Freedom? Consequences Following From Contemporary Economic Crisis
}

JEL Classification: $E 12, E 13, E 32, E 44$

Keywords: economic crisis, economic freedom

\begin{abstract}
The paper is aimed at stating if economic crisis observed during the period 2007-2009 will give rise to greater or reduced economic freedom. Seeking the answer to this question, Economic Freedom Index developed by Fraser Institute during the period 2007-2010 was subject to analysis. The research covered the European Union and the United States of America.
\end{abstract}

\section{Wprowadzenie}

Cechą nieodłączną kapitalizmu jest jego cykliczność. Co pewien okres pojawiają się więc kryzysy gospodarcze, które mają rozmaitą specyfikę, siłę i zakres. Największe kryzysy wpływają na zmiany modeli ustroju rynkowego. Kryzys trwający od końca lat dwudziestych i w zasadzie do połowy lat trzydziestych XX wieku spowodował spadek wolności gospodarczej w postaci rozwoju interwencjonizmu państwowego ${ }^{1}$, natomiast kryzys „naftowy” lat siedemdziesiątych spowodował pewien zwrot ku liberalizmowi gospodarczemu i tym samym wzrost wolności gospodarczej. Postawić można zatem pytanie, czy obecny kryzys spowoduje powrót do interwencjonizmu państwowego, czego przejawem byłoby ograniczenie wolności gospodarczej, czy też wzrost wolności gospodarczej?

\section{Metodyka badań}

Celem niniejszego opracowania jest poszukiwanie odpowiedzi na pytanie, czy kryzys gospodarczy lat 2007-2009, który można umownie nazwać współczesnym kryzysem gospodarczym lub też finansowo-gospodarczym, spowoduje spadek czy wzrost wolności gospodarczej. Poszukując odpowiedzi na to pytanie przeprowadzono analizę raportów Instytutu Frasera

\footnotetext{
${ }^{1} \mathrm{~W}$ pewnym uproszczeniu przyjęto $\mathrm{w}$ artykule utożsamiać spadek wolności $\mathrm{z}$ interwencjonizmem.
} 
i Indeksów Wolności Gospodarczej (IWG) w latach 2007-2010. Badaniami objęto Unię Europejską i Stany Zjednoczone. Do badań wybrano Indeks Wolności Gospodarczej Instytutu Frasera, gdyż w porównaniu do innych indeksów odnoszących się do wolności gospodarczej, obejmuje on najdłuższy szereg czasowy, umożliwiający odniesienia również do kryzysu lat siedemdziesiątych. Przyjęto przy tym pewne uproszczenie, że spadek wolności gospodarczej związany jest z interwencjonizmem.

\section{Interwencjonizm państwa a wolność gospodarcza}

W latach trzydziestych XX. wieku został zapoczątkowany dyskurs między zwolennikami interwencjonizmu państwowego i wolności gospodarczej, często traktowany jako spór między J.M. Keynesem a F.A. Hayekiem i zwolennikami ich poglądów. Spór ten toczył się z różnym natężeniem przez kolejne dziesięciolecia. Pozostaje on aktualny również obecnie, w dobie kryzysu gospodarczego, czy też kolejnej fali tego kryzysu. Można zatem postawić pytanie, czy obecny kryzys spowoduje podążanie w stronę interwencjonizmu czy wolności gospodarczej.

Czym zatem jest interwencjonizm państwowy? Ogólnie, jest to aktywna rola państwa na rynku. Zwolennicy interwencjonizmu uważają, że przyczyną problemów gospodarczych, w tym na przykład dużego bezrobocia, jest niewystarczający popyt globalny. Niejako przeciwieństwem interwencjonizmu jest wolność gospodarcza. Kryteriami jej oceny gospodarczej są: możliwość wolnego wyboru (podejmowania decyzji) dokonywanego przez jednostki (obywateli), swoboda wymiany rynkowej, wolność konkurowania, oraz bezpieczeństwo prywatnej własności (Opala, Rzońca 2008, s. 1120).

J.D. Gwartney, R. Lawson, J. Hall, autorzy publikacji i indeksu „Economic Freedom of the World" wydawanych przez Instytut Frasera (Gwartney i inni 2012), definiują wolność gospodarczą poprzez przyporządkowanie jej kilku elementów składowych. Za takie uznają: prawo obywateli do podejmowania niezależnych i swobodnych decyzji gospodarczych, dobrowolną wymianę koordynowaną przez rynek, wolny dostęp i konkurencję na rynkach, ochronę osób i ich własności przed agresją ze strony innych osób oraz gwarancję dobrej jakości pieniądza (Gwartney i inni 2012, s. 1-2). Te elementy były podstawą do budowy, opracowanego przez Instytut Frasera, Indeksu Wolności Gospodarczej (w skrócie IWG) mierzącego stopień, $\mathrm{w}$ jakim otoczenie instytucjonalne i polityka rządowa w poszczególnych krajach przyczyniają się do zwiększenia wolności gospodarczej. Czterdzie- 
ści dwie zmienne, z których składa się IWG, zostały podzielone na pięć obszarów (Gwartney i inni 2012, s. 5):

- władza albo miejsce sektora państwowego (zakres wydatków państwowych, skala opodatkowania gospodarki i społeczeństwa oraz rola przedsiębiorstw państwowych w gospodarce),

- system prawny i ochrona praw własności,

- stabilność pieniądza i dostęp do niego,

- swoboda handlu międzynarodowego i przepływów kapitałowych,

- skala regulacji gospodarczych dotyczących kredytów, rynku pracy, działalności gospodarczej.

Indeks Wolności Gospodarczej przyjmuje wartości od 0 do 10, gdzie 10 obrazuje pełną wolność gospodarczą. Ocena całościowa jest średnią arytmetyczną z przedstawionych wyżej pięciu obszarów wolności ocenianych również w skali od 0 do 10 . Indeks ten jest i publikowany od lat dziewięćdziesiątych. Wcześniej analizowano zdecydowanie mniejszą liczbę krajów. Dlatego też ten wskaźnik do analizy kryzysu roku w 1973 (tabela 3) można wykorzystać jedynie dla 14 krajów w Europie, a dane obejmują lata 1970, 1975 i 1980 . Dopiero od 2000 roku indeks ten wyznaczany jest dla każdego roku.

\section{Kryzys gospodarczy lat 2007-2009}

Oznaką kryzysu gospodarczego jest przede wszystkim ujemne tempo wzrostu gospodarczego, ale również wzrost stopy bezrobocia, duże wahania stopy inflacji, spadek produkcji, znaczne zmniejszenie obrotów handlowych z zagranicą itd. Poprzedni duży kryzys, który silnie dotknął kraje europejskie w 1973 r, wystąpił na skutek znaczącego wzrostu cen ropy. Obecny kryzys, zapoczątkowany w Stanach Zjednoczonych, który został wywołany na rynku nieruchomości, wpłynął negatywnie na rynki finanso$\mathrm{we}^{2}$. Na rynku nieruchomości w USA miał miejsce wieloletni wzrost popytu m.in. dzięki udzielanym niskoprocentowym kredytom osobom mało zamożnym, które otrzymywały gwarancje kredytowe Federalnej Administracji Mieszkaniowej. Dodać należy, że banki szukając bardziej rentownych aktywów korzystały z instrumentów opartych na kredytach hipotecznych, co dodatkowo powodowało wzrost deficytów na rynkach finansowych. Finansiści wiedzieli, że w razie trudności mogą liczyć na pomoc rządu, gdy „napompowana bańka” na rynku nieruchomości pękła. Zaczęto

${ }^{2}$ Zob. też interesujące rozważania na temat zmian w istocie funkcjonowania banków (Wechta 2012, s. 3-5). 
obniżać stopy procentowe w USA, co spowodowało deprecjację dolara, wzrost cen ropy i w efekcie osłabienie gospodarki amerykańskiej. Reasumując przyczyny analizowanego kryzysu to: brak należytych ram prawnych dla transakcji na kredyty mieszkaniowe, tworzenie nowych błędnych instrumentów finansowych i brak odpowiedzialnego nadzoru systemu bankowego. Przyczyny te zostały niejako wzmocnione przez czynniki ekonomii behawioralnej (Szyszka 2009, s. 5-30).

Kryzys pojawił się w USA pod koniec 2007 roku w postaci spadku cen nieruchomości i niedoboru zasobów pieniądza. W kolejnych kwartałach zaczął obejmować kraje europejskie, począwszy od Islandii.

Poniżej (tabele 1, 2, 3 i 4) zaprezentowano najbardziej wymierne wskaźniki obrazujące sytuację gospodarczą w latach 2007-2011 - wskaźnik zmian wielkości PKB, eksportu i importu oraz stopy bezrobocia.

Jak widać w danych tabeli 1, w 2009 roku nastąpiło apogeum kryzysu gospodarczego. Nastąpił spadek PKB (w USA już w 2008 roku) i wzrost stopy bezrobocia. Dane przedstawione $\mathrm{w}$ tabeli 1 pokazują szczegółowo zmiany PKB w UE i USA w latach 2007-2011. W przedkryzysowym (biorąc pod uwagę dodatni wskaźnik PKB) 2007 roku wskaźnik wzrostu gospodarczego wynosił w UE ponad 3\%. Największy był na Słowacji, Litwie i Łotwie (około $10 \%$ ) oraz $\mathrm{w}$ Estonii $(7,5 \%$ ); najniższy na Węgrzech $(0,1 \%)$, w Danii $(1,6 \%)$ i we Włoszech $(1,7 \%)$. W każdym kraju UE był dodatni.

W 2008 roku wskaźnik wzrostu gospodarczego w UE wynosił zaledwie 0,3\%. Największy był w Rumunii (ponad 7\%), Bułgarii i na Słowacji (około 6\%), a w 9 krajach był ujemny.

W 2009 roku wskaźnik PKB w UE wyniósł -4,3\% PKB. Jedynym krajem, w którym nastąpił wzrost wskaźnika PKB była Polska. W pozostałych krajach wskaźnik był ujemy, przy czym najniższy był na Łotwie (prawie $-18 \%$ ), na Litwie (prawie -15\%) i w Estonii (około -14\%).

W 2010 roku zanotowano w UE wzrost wskaźnika PKB o 2,0 \%. W 22 krajach odnotowano wzrost tego wskaźnika, największy na Słowacji i w Polsce (około 4\%). Największy spadek nastąpił w Grecji (-3,5\%) i w Rumunii (prawie $-2 \%$ ).

W 2011 roku wzrost wskaźnika PKB w UE wyniósł 1,5\%, czyli mniej niż w 2010 roku. Dane statystyczne, dla niektórych krajów będące jeszcze prognozami, pokazują, że największy wzrost miał miejsce w Estonii (7,5\%), na Litwie (prawie 6\%) i na Łotwie (ponad 5\%). Spadek wskaźnika nastąpił w Grecji (o prawie 7\%), w Portugalii (o ponad 3\%) i w Słowenii (niewiele poniżej 0\%). 
Z powyższych danych dotyczących zmian wskaźnika wzrostu PKB w poszczególnych krajach UE oraz w USA można wyciągnąć wniosek, że szczyt kryzysu gospodarczego dotknął te kraje najmocniej w 2009 roku.

Tabela 1. Dynamika PKB w UE w latach 2007-2011 (w \%)

\begin{tabular}{|l|c|c|c|c|c|}
\hline \multicolumn{1}{|c|}{ Kraje } & $\mathbf{2 0 0 7}$ & $\mathbf{2 0 0 8}$ & $\mathbf{2 0 0 9}$ & $\mathbf{2 0 1 0}$ & $\mathbf{2 0 1 1}$ \\
\hline EU(27) & 3,2 & 0,3 & $-4,3$ & 2,0 & 1,5 \\
\hline Belgia & 2,9 & 1,0 & $-2,8$ & 2,3 & 1,9 \\
\hline Bułgaria & 6,4 & 6,2 & $-5,5$ & 0,4 & 1,7 \\
\hline Czechy & 5,7 & 3,1 & $-4,7$ & 2,7 & 1,7 \\
\hline Dania & 1,6 & $-0,8$ & $-5,8$ & 1,3 & 1,0 \\
\hline Niemcy & 3,3 & 1,1 & $-5,1$ & 3,7 & 3,0 \\
\hline Estonia & 7,5 & $-3,7$ & $-14,3$ & 2,3 & 7,5 \\
\hline Irlandia & 5,2 & $-3,0$ & $-7,0$ & $-0,4$ & 0,9 \\
\hline Grecja & 3,0 & $-0,2$ & $-3,3$ & $-3,5$ & $-6,8$ \\
\hline Hiszpania & 3,5 & 0,9 & $-3,7$ & $-0,1$ & 0,7 \\
\hline Francja & 2,3 & $-0,1$ & $-2,7$ & 1,5 & 1,7 \\
\hline Włochy & 1,7 & $-1,2$ & $-5,1$ & 1,5 & 0,2 \\
\hline Cypr & 5,1 & 3,6 & $-1,9$ & 1,1 & 0,5 \\
\hline Łotwa & 9,6 & $-3,3$ & $-17,7$ & $-0,3$ & 5,3 \\
\hline Litwa & 9,8 & 2,9 & $-14,8$ & 1,4 & 5,9 \\
\hline Luksemburg & 6,6 & 0,8 & $-5,3$ & 2,7 & 1,1 \\
\hline Węgry & 0,1 & 0,9 & $-6,8$ & 1,3 & 1,7 \\
\hline Malta & 4,3 & 4,4 & $-2,7$ & 2,9 & 2,1 \\
\hline Holandia & 3,9 & 1,8 & $-3,5$ & 1,7 & 1,2 \\
\hline Austria & 3,7 & 1,4 & $-3,8$ & 2,3 & 3,1 \\
\hline Polska & 6,8 & 5,1 & 1,6 & 3,9 & 4,3 \\
\hline Portugalia & 2,4 & 0,0 & $-2,5$ & 1,4 & $-3,3$ \\
\hline Rumunia & 6,3 & 7,3 & $-6,6$ & $-1,9$ & 2,5 \\
\hline Słowenia & 6,9 & 3,6 & $-8,0$ & 1,4 & $-0,2$ \\
\hline Słowacja & 10,5 & 5,9 & $-4,9$ & 4,2 & 3,3 \\
\hline Finlandia & 5,3 & 1,0 & $-8,2$ & 3,6 & 2,9 \\
\hline Szwecja & 3,3 & $-0,6$ & $-5,2$ & 5,6 & 3,9 \\
\hline Wielka Brytania & 3,5 & $-1,1$ & $-4,4$ & 1,8 & 0,8 \\
\hline USA & 1,9 & $-0,3$ & $-3,5$ & 3,0 & 1,7 \\
\hline & & & & & \\
\hline
\end{tabular}

Uwaga dotycząca 2011 roku: dane rzeczywiste dla UE, Danii, Niemiec, Litwy, Finlandii, Szwecji, Wielkiej Brytanii i USA. Informacje dla pozostałych krajów to prognozy (dostęp 1.03.2012).

Źródło: Eurostat http://epp.eurostat.ec.europa.eu/tgm/table.do?tab=table\&init=1\&language $=\mathrm{de} \&$ pode $=$ tsieb020\&plugin $=1$. 
Innym ważnymi miernikami obrazującym kryzys gospodarczy są zmiany w eksporcie $\mathrm{i}$ imporcie oraz stopie bezrobocia (tabele 2, 3 i 4).

Tabela 2. Tempo zmian w eksporcie krajów UE w latach 2007-2011 (2000 rok= 100)

\begin{tabular}{|l|r|r|r|r|r|}
\hline \multicolumn{1}{|c|}{ Kraje } & $\mathbf{2 0 0 7}$ & $\mathbf{2 0 0 8}$ & $\mathbf{2 0 0 9}$ & $\mathbf{2 0 1 0}$ & $\mathbf{2 0 1 1}$ \\
\hline Belgia & 114 & 118 & 110 & 118 & 126 \\
\hline Bułgaria & 132 & 141 & 128 & 141 & 155 \\
\hline Czechy & 121 & 127 & 123 & 129 & 137 \\
\hline Dania & 107 & 112 & 106 & 112 & 119 \\
\hline Niemcy & 111 & 113 & 113 & 116 & 122 \\
\hline Estonia & 114 & 120 & 112 & 120 & 131 \\
\hline Irlandia & 98 & 98 & 96 & 100 & 101 \\
\hline Grecja & 116 & 122 & 110 & 119 & 129 \\
\hline Hiszpania & 118 & 122 & 117 & 123 & 130 \\
\hline Francja & 114 & 119 & 116 & 120 & 126 \\
\hline Włochy & 121 & 127 & 124 & 129 & 138 \\
\hline Cypr & 118 & 130 & 109 & 118 & 127 \\
\hline Łotwa & 129 & 134 & 121 & 131 & 141 \\
\hline Litwa & 122 & 134 & 116 & 130 & 146 \\
\hline Luksemburg & 94 & 91 & 84 & 89 & 94 \\
\hline Węgry & 98 & 100 & 96 & 105 & 109 \\
\hline Malta & 99 & 106 & 113 & 123 & 138 \\
\hline Holandia & 108 & 112 & 104 & 114 & 125 \\
\hline Austria & 111 & 114 & 112 & 114 & 119 \\
\hline Polska & 121 & 127 & 119 & 127 & 134 \\
\hline Portugalia & 109 & 111 & 107 & 115 & 123 \\
\hline Rumunia & 127 & 134 & 125 & 135 & 148 \\
\hline Słowenia & 116 & 119 & 115 & 120 & 127 \\
\hline Słowacja & 120 & 122 & 116 & 119 & 125 \\
\hline Finlandia & 112 & 111 & 104 & 113 & 121 \\
\hline Szwecja & 107 & 109 & 102 & 112 & 119 \\
\hline Wielka Brytania & 114 & 117 & 110 & 122 & 131 \\
\hline & & & & & \\
\hline
\end{tabular}

Źródło: http://epp.eurostat.ec.europa.eu/portal/page/portal/statistics/search_database.

Dane zawarte w tabeli 2 pokazują, że w 2009 roku, poza Maltą (wzrost) i Niemcami (bez zmian), we wszystkich krajach unijnych nastąpił spadek eksportu. Największy spadek nastąpił na Litwie, w Bułgarii, Łotwie, na Cyprze, w Grecji, czyli w krajach słabiej rozwiniętych, najmniejszy w wysokorozwiniętych. W 2010 roku nastąpił natomiast wzrost eksportu we 
wszystkich krajach Unii Europejskiej i wzrost ten był kontynuowany we wszystkich krajach unijnych w 2011 roku. Zależności te warto odnieść to zmian w imporcie w latach 2007-2011 (tabela 3).

Tabela 3. Tempo zmian $\mathrm{w}$ imporcie krajów UE w latach 2007-2011 (2000 rok= 100)

\begin{tabular}{|l|c|c|c|c|c|}
\hline \multicolumn{1}{|c|}{ Kraje } & $\mathbf{2 0 0 7}$ & $\mathbf{2 0 0 8}$ & $\mathbf{2 0 0 9}$ & $\mathbf{2 0 1 0}$ & $\mathbf{2 0 1 1}$ \\
\hline Belgia & 114 & 123 & 111 & 122 & 132 \\
\hline Bułgaria & 126 & 133 & 118 & 130 & 144 \\
\hline Czechy & 116 & 124 & 116 & 125 & 133 \\
\hline Dania & 106 & 110 & 107 & 112 & 119 \\
\hline Niemcy & 116 & 121 & 114 & 121 & 131 \\
\hline Estonia & 118 & 127 & 113 & 123 & 136 \\
\hline Irlandia & 102 & 104 & 98 & 103 & 110 \\
\hline Grecja & 124 & 134 & 122 & 133 & 146 \\
\hline Hiszpania & 124 & 132 & 121 & 131 & 144 \\
\hline Francja & 119 & 127 & 121 & 129 & 141 \\
\hline Włochy & 121 & 130 & 121 & 132 & 145 \\
\hline Cypr & 116 & 122 & 112 & 121 & 132 \\
\hline Lotwa & 118 & 129 & 116 & 123 & 136 \\
\hline Litwa & 124 & 140 & 119 & 136 & 155 \\
\hline Luksemburg & 110 & 111 & 101 & 111 & 121 \\
\hline Węgry & 106 & 108 & 102 & 107 & 112 \\
\hline Malta & 93 & 100 & 95 & 93 & 101 \\
\hline Holandia & 112 & 119 & 109 & 121 & 132 \\
\hline Austria & 117 & 124 & 119 & 125 & 134 \\
\hline Polska & 118 & 126 & 114 & 125 & 135 \\
\hline Portugalia & 117 & 123 & 113 & 125 & 154 \\
\hline Rumunia & 117 & 124 & 115 & 123 & 134 \\
\hline Słowenia & 119 & 125 & 116 & 125 & 134 \\
\hline Słowacja & 122 & 129 & 119 & 126 & 134 \\
\hline Finlandia & 119 & 124 & 112 & 124 & 137 \\
\hline Szwecja & 112 & 116 & 107 & 118 & 128 \\
\hline Wielka Brytania & 111 & 112 & 107 & 119 & 130 \\
\hline & & & & & \\
\hline
\end{tabular}

Źródło: http://epp.eurostat.ec.europa.eu/portal/page/portal/statistics/search_database.

Jak pokazują dane zawarte $\mathrm{w}$ tabeli 3, również w przypadku importu dóbr do poszczególnych krajów Unii Europejskiej w 2009 roku nastąpiło jego załamanie i zmalał on do wszystkich krajów unijnych w stosunku do roku 2008 i 2007. Największy spadek importu nastąpił na Litwie, w Esto- 
nii, Grecji, na Łotwie, w Polsce Bułgarii, czyli również w krajach słabiej rozwiniętych. Analogicznie, jak to było w przypadku eksportu, w 2010 roku nastąpił wzrost importu do wszystkich krajów unijnych i w 2011 roku wzrost ten był kontynuowany.

Tabela 4. Stopa bezrobocia w UE w latach 2007-2011

\begin{tabular}{|l|c|c|c|r|r|}
\hline \multicolumn{1}{|c|}{ Kraje } & $\mathbf{2 0 0 7}$ & $\mathbf{2 0 0 8}$ & $\mathbf{2 0 0 9}$ & $\mathbf{2 0 1 0}$ & $\mathbf{2 0 1 1}$ \\
\hline UE 27 & 7,2 & 7,1 & 9,0 & 9,7 & 9,6 \\
\hline Belgia & 7,5 & 7,0 & 7,9 & 8,3 & 7,2 \\
\hline Bułgaria & 6,9 & 5,6 & 6,8 & 10,3 & 11,3 \\
\hline Czechy & 6,3 & 4,4 & 6,7 & 7,3 & 6,7 \\
\hline Dania & 3,8 & 3,4 & 6,0 & 7,5 & 7,6 \\
\hline Niemcy & 8,7 & 7,5 & 7,8 & 7,1 & 5,9 \\
\hline Estonia & 4,6 & 5,5 & 13,2 & 16,9 & 12,5 \\
\hline Irlandia & 4,7 & 6,4 & 12,0 & 13,9 & 14,7 \\
\hline Grecja & 8,3 & 7,7 & 9,5 & 12,6 & 17,7 \\
\hline Hiszpania & 8,3 & 11,3 & 18,0 & 20,1 & 21,7 \\
\hline Francja & 8,4 & 7,8 & 9,5 & 9,7 & 9,6 \\
\hline Włochy & 6,1 & 6,7 & 7,8 & 8,4 & 8,4 \\
\hline Cypr & 4,1 & 3,8 & 5,5 & 6,5 & 7,9 \\
\hline Lotwa & 6,5 & 8,0 & 18,2 & 19,8 & 16,2 \\
\hline Litwa & 3,8 & 5,3 & 13,6 & 18,0 & 15,3 \\
\hline Luksemburg & 4,2 & 4,9 & 5,1 & 4,6 & 4,8 \\
\hline Węgry & 7,4 & 7,8 & 10,0 & 11,2 & 10,9 \\
\hline Malta & 6,5 & 6,0 & 6,9 & 6,9 & 6,5 \\
\hline Holandia & 3,6 & 3,1 & 3,7 & 4,5 & 4,4 \\
\hline Austria & 4,4 & 3,8 & 4,8 & 4,4 & 4,2 \\
\hline Polska & 9,6 & 7,0 & 8,1 & 9,6 & 9,6 \\
\hline Portugalia & 8,9 & 8,5 & 10,6 & 12,0 & 12,9 \\
\hline Rumunia & 6,4 & 5,8 & 6,9 & 7,3 & 7,4 \\
\hline Słowenia & 4,9 & 4,4 & 5,9 & 7,3 & 8,2 \\
\hline Słowacja & 11,2 & 9,6 & 12,1 & 14,5 & 13,6 \\
\hline Finlandia & 6,9 & 6,4 & 8,2 & 8,4 & 7,8 \\
\hline Szwecja & 6,1 & 6,2 & 8,3 & 8,4 & 7,5 \\
\hline Wielka Brytania & 5,3 & 5,6 & 7,6 & 7,8 & 8,0 \\
\hline USA & 4,6 & 5,8 & 9,3 & 9,6 & 8,9 \\
\hline & & & & & \\
\hline
\end{tabular}

Źródło: http://epp.eurostat.ec.europa.eu/portal/page/portal/statistics/search_database. 
O ile w 2008 roku stopa bezrobocia minimalnie spadła w Unii Europejskiej, to w 2009 roku nastąpił jej wzrost aż o prawie 2 punkty procentowe (tabela 4). W przeciwieństwie do danych z tabel 1, 2 i 3, sytuacja na rynku pracy w 2010 uległa dalszemu pogorszeniu i nastąpił dalszy wzrost stopy bezrobocia. Uległ on wyhamowaniu w 2011 roku.

Największy przyrost stopy bezrobocia odnotowano w Hiszpanii, Grecji i krajach nadbałtyckich oraz w USA, a najmniejszy w Luksemburgu, Austrii i Holandii. Można zaobserwować bardzo dużą różnicę między krajami w wysokości stopy bezrobocia. Sięga ona około $20 \%$.

Przedstawione dane dotyczące zmian PKB, eksportu i importu oraz stopy bezrobocia pokazują, że kryzys objął wszystkie kraje Unii Europejskiej.

\section{Zmiany wielkości indeksu wolności gospodarczej Instytutu Frasera}

Warto przedstawić ocenę współczesnego kryzysu finansowogospodarczego. Jako narzędzie wykorzystano Indeks Wolności Gospodarczej Instytutu Frasera.

Opracowania Instytutu Frasera dokonywane w latach 2007, 2008, 2009 i 2010 pozwalają wstępnie odpowiedzieć na pytanie, które kraje mają systemy gospodarcze bardziej interwencjonistyczne, a które bardziej liberalne. Pozwalają też na pewne porównania $\mathrm{z}$ kryzysem lat siedemdziesiątych. Tym celom służą tabele 5, 6 i 7.

Tabela 5. Indeks Wolności Gospodarczej Instytutu Frasera i jego zmiany w latach 2007-2010

\begin{tabular}{|c|c|c|c|c|c|}
\cline { 2 - 6 } \multicolumn{1}{c|}{} & $\mathbf{2 0 0 7}$ & $\mathbf{2 0 0 8}$ & $\mathbf{2 0 0 9}$ & $\mathbf{2 0 1 0}$ & $\begin{array}{c}\text { Zmiana } \\
\mathbf{2 0 0 9 / 2 0 0 7}(\mathbf{w} \%)\end{array}$ \\
\hline UE 27 & 7,53 & 7,47 & 7,39 & 7,39 & $-1,9$ \\
\hline USA & 8,21 & 7,99 & 7,72 & 7,70 & $-6,2$ \\
\hline
\end{tabular}

Źródło: (Gwartney i inni 2012, s. 15-18).

W latach 2007-2009 następował spadek IWG zarówno w UE jak i w USA, przy czym w USA był zdecydowanie większy, bo o $6,2 \%$, podczas gdy w UE o 1,9\% (tabela 5). W 2010 roku nastąpiło wyhamowanie spadków IWG - w Unii Europejskiej nie zmienił się w stosunku do 2009 roku a w USA minimalnie spadł. 
W tabeli 6 uwzględniono z kolei zmiany IWG w wybranych grupach krajów.

Tabela 6. Spadek IWG w latach 2007-2009 w USA i UE

\begin{tabular}{|c|c|}
\cline { 2 - 2 } \multicolumn{1}{c|}{} & Spadek IWG w latach 2007-2009 (\%) \\
\hline USA & 6,2 \\
\hline UE 27 & 1,9 \\
\hline UE 17 & 2,5 \\
\hline UE 15 & 2,6 \\
\hline UE 10 & 1,1 \\
\hline
\end{tabular}

Źródło: (Gwartney i inni 2012, s. 15-18).

Jak wynika $\mathrm{z}$ danych tabeli 6 , w UE największy spadek miał miejsce w krajach dawnej UE a najmniejszy w krajach nowej UE. Można też zaobserwować, uwzględniając również dane z tabeli 4, że największy spadek nastąpił tam, gdzie wielkość IWG była największa a najmniejszy tam, gdzie była najmniejsza.

Dla porównania zmian wielkości IWG podczas współczesnego kryzysu przedstawiono (tabela 6) te zmiany w okresie obejmującym kryzys naftowy (lata 1973-1974).

Analizując wielkość indeksu przed i po kryzysie 1973 roku (tabela 7) można zauważyć, że w 1975 roku jego poziom obniżył się w krajach europejskich o prawie $10 \% \mathrm{w}$ stosunku do 1970 roku, po czym, w kolejnych latach wolność gospodarcza wzrosła do poziomu niewiele niższego niż w roku 1970. W USA wskaźnik ten wzrósł w roku 1975 w stosunku do 1970. Można więc wysunąć wniosek, zgodny również z literaturą przedmiotu, że kryzys lat siedemdziesiątych spowodował jedynie krótkookresowe odwrócenie od liberalizmu.

Tabela 7. Indeks Wolności Gospodarczej Instytutu Frasera i jego zmiany w latach 1970-1980

\begin{tabular}{|l|c|c|c|c|}
\hline \multicolumn{1}{|c|}{ Kraje } & $\mathbf{1 9 7 0}$ & $\mathbf{1 9 7 5}$ & $\mathbf{1 9 8 0}$ & $\begin{array}{c}\text { Zmiana } \\
\mathbf{1 9 7 5 / 1 9 7 0}(\mathbf{w} \%)\end{array}$ \\
\hline Kraje Europy* & 6,83 & 6,16 & 6,61 & $-9,8$ \\
\hline Dania & 7,05 & 6,33 & 6,53 & $-10,2$ \\
\hline Niemcy & 7,69 & 7,11 & 7,37 & $-7,5$ \\
\hline Irlandia & 7,12 & 6,20 & 6,73 & $-12,9$ \\
\hline Grecja & 6,35 & $\underline{5,99}$ & $\underline{5,97}$ & $-5,7$ \\
\hline
\end{tabular}


Tabela 7 ciąg dalszy

\begin{tabular}{|l|c|c|c|c|}
\hline \multicolumn{1}{|c|}{ Kraje } & $\mathbf{1 9 7 0}$ & $\mathbf{1 9 7 5}$ & $\mathbf{1 9 8 0}$ & $\begin{array}{c}\text { Zmiana } \\
\mathbf{1 9 7 5 / 1 9 7 0}(\mathbf{w} \%)\end{array}$ \\
\hline Hiszpania & 6,71 & 6,02 & 6,19 & $-10,3$ \\
\hline Francja & 6,86 & 6,01 & 6,22 & $-12,4$ \\
\hline Włochy & 6,08 & 5,33 & 5,53 & $-12,3$ \\
\hline Luksemburg & $\mathbf{7 , 5 9}$ & $\underline{\mathbf{7 , 6 4}}$ & $\underline{\mathbf{7 , 5 8}}$ & $\mathbf{0 , 7}$ \\
\hline Holandia & $\mathbf{7 , 6 4}$ & 6,96 & 7,01 & $-8,9$ \\
\hline Austria & 6,63 & 6,28 & 6,76 & $-5,3$ \\
\hline Portugalia & 6,37 & 4,28 & 5,99 & $-32,8$ \\
\hline Finlandia & 7,13 & 6,39 & 6,95 & $-10,4$ \\
\hline Szwecja & 5,77 & 5,64 & 5,95 & $-2,3$ \\
\hline Wielka Brytania & 6,59 & 6,29 & 6,73 & $-4,6$ \\
\hline USA & $\mathbf{7 , 7 4}$ & $\mathbf{7 , 8 3}$ & 8,03 & $\mathbf{1 , 2}$ \\
\hline
\end{tabular}

* - średnia arytmetyczna dla krajów unijnych

Źródło: (Gwartney i inni 2012, s. 15-18).

$\mathrm{Z}$ przedstawionych danych $\mathrm{w}$ tabelach 5,6 i 7 można wywnioskować, że w latach 2008-2009 nastąpiło zmniejszenie IWG. Jego skala była jednak znacznie mniejsza niż w roku 1975 w stosunku do roku 1970.

\section{Zakończenie}

Kryzys gospodarczy, który miał swoje apogeum w 2009 roku nie spowodował, jak dotychczas, znaczących zmian w zakresie wolności gospodarczej w krajach Unii Europejskiej. Zmniejszyła się ona w niewielkim stopniu, szczególnie w porównaniu ze zmianami notowanymi w okresie kryzysu w latach 70. Co wydaje się być istotne, można zaobserwować wyhamowanie spadku wartości IWG w 2010 roku. Istotne będą zatem dane za kolejne lata. Trudno więc ustalić, czy w kolejnych latach nastąpi wzrost, utrzymanie czy też spadek poziomu wolności gospodarczej.

Większy spadek IWG nastąpił w krajach o wyższej wartości tego indeksu. Warto zauważyć, że dane dotyczące wielkości PKB, również te podawane na bieżąco przez Eurostat wskazują, że kryzys nadal trwa. Biorąc pod uwagę również niewielkie dotychczasowe zmiany IWG brak jest jednoznacznej odpowiedzi, czy w jego wyniku nastąpi spadek czy wzrost wolności gospodarczej.

$\mathrm{Na}$ koniec pewna refleksja. W dwóch poprzednich światowych kryzysach, tj w latach 1929-1933(5) i 1973 roku, nastąpiły istotne zmiany w interwencji państwa w gospodarce. Kryzys pierwszy spowodował wzrost 
interwencjonizmu i po II wojnie światowej uczynił bardzo popularnym teorię Keynesa. Być może, gdyby nie druga wojna światowa, podczas której USA miały rocznie około $30 \%$ wzrost PKB, gdyż produkowały uzbrojenie dla wielu krajów, nie rozwijałyby się tak szybko i keynesism nie zyskałby popularności i znaczenia. Gospodarka USA, wbrew założeniom, mogłaby nie ożywić się po wzroście wydatków z budżetu USA w drugiej połowie lat 30 . Po kryzysie lat 70, szczególnie po dojściu do władzy Reagana, Teacher i Kohla ich gospodarki zwiększyły orientację na liberalizm. Być może była to częściowo pozorna orientacja.

Pewnym zagrożeniem obecnego kryzysu jest stosunkowo często spotykane $\mathrm{w}$ mediach negatywne podejście do wolności gospodarczej. $Z$ drugiej strony - zbyt mało podkreślane są pozytywne aspekty działań w warunkach wolności gospodarczej, szczególnie tej w rozumieniu Smitha - wolności opartej na uczciwości.

\section{Literatura}

Ayal, E.B., Karras G., (1998), Components of Economic Freedom and Growth: AnEmpirical Study, "Journal of Developing Areas", Vol. 32, No. 3.

Buiter W.H., (2009), Lesson from Global Crisis for Social Democrats, European Institute, London School of Economics and Political Sciences, CEPR and NBR, 2009 www.nber.org/ wbuiter/uyl.pdf, (1.01.2012).

Gwartney, J. D., Holcombe R. G., Lawson R. A., (2006), Institutions and the Impact of Investment on Growth, "Kyklos", Vol. 59, No. 2.

Gwartney J., Lawson R., Hall J., (2012), Economic Freedom of the World, Annual Report, www.fraserinstitut.org.

Hayek, F.A., (1996), Droga do zniewolenia, Arcana, Kraków.

Keynes J.M., (2003), Ogólna teoria zatrudnienia, procentu i pieniadza, PWN, Warszawa.

Opala P., Rzońca A., (2008), Ile wolności gospodarczej, Zeszyty FOR http://www.for.org.pl/upload/File/zeszyty/Zeszyt_Ile_wolnosci_gospodarczej_ Opala.pdf.

Szyszka A., (2009), Behawioralne aspekty kryzysu finansowego, „Bank i kredyt”, Vol. 40, No. 4.

Szymański W., (2009), Kryzys globalny, Pierwsze przybliżenie, Difin, Warszawa. Wechta P., (2012), Władza banku. Koncepcja Talcotta Pearsona a wspótczesny kryzys finansowy, „Przegląd Organizacji”, nr 3.

$\mathrm{http}$ ://epp.eurostat.ec.europa.eu/tgm/table.do?tab=table\&init=1\&plugin=1\&langua $\mathrm{ge}=\mathrm{de} \& \mathrm{pcode}=\mathrm{tsieb} 020$.

http://epp.eurostat.ec.europa.eu/portal/page/portal/statistics/search_database. www.tradingeconomics.com. 